УДК 378.018.8.376-056.264-051

DOI: 10.37026/2520-6427-2019-99-3-95-99
Світлана ЦИМБАЛ-СЛАТВІНСЬКА,

кандидатка педагогічних наук,

доцентка кафедри спеціальної освіти

Уманського державного педагогічного

університету імені Павла Тичини

\title{
ПЕДАГОГІЧНІ УМОВИ ПРОФЕСІЙНОЇ ПІДГОТОВКИ МАЙБУТНІХ ЛОГОПЕДІВ В ІНФОРМАЦІЙНО-ОСВІТНЬОМУ СЕРЕДОВИЩІ УНІВЕРСИТЕТУ
}

У статті обтрунтовано комплекс педагогічних умов професійної підготовки майбутніх логопедів в інформачійно-освітньому середовищі закладів вищоі освіти. Подано трактування комплексу педагогічних умов, під якими розуміємо сукупність взаємопов'язаних чинників та заходів освітнього процесу, дотримання яких забезпечує досягнення студентами більш високого рівня готовності до професійної діяльності. Визначено такі групи умов: перша група, щзо відображає процес иілеспрямованого використання потенціалу фахових дисииплін у професійній підготовиі майбутніх логопедів через теоретичну підготовку та практичну діяльність, спрямовану на роботу з дітьми з порушенням мовлення; друга - орієнтує на формування в майбутніх логопедів готовності до роботи в розвивально-корекиійному режимі (мотивації, потреби, здатності, рішучості до саморозвитку, рефлексії, емпатії, творчої активності) 3 використанням інноваційних форм, активних методів та інформаційно-комунікаційних технологій; третя - спрямована на розвиток професійних умінь $i$ навичок, зокрема через корекиійно-логопедичну роботу засобами моделювання артикуляиії звуків.

Ключові слова: комплекс, педагогічні умови, професійна підготовка, майбутні логопеди, інформаційноосвітнє середовище.

В статье обоснован комплекс педагогических условий профессиональной подготовки будущих логопедов в информационно-образовательной среде высших учебных заведений. Дается трактовка комплекса педагогических условий, под которыми понимаем совокупность взаимосвязанных факторов и мероприятий образовательного прочесса, соблюдение которых обеспечивает достижение студентами более высокого уровня готовности к профессиональной деятельности. Определены следуюшие группь условий: первая группа, которая отражает проиесс иеленаправленного использования потенцииала профессиональных дисииплин в профессиональной подготовке будущих логопедов через теоретическую подготовку и практическую деятельность, направленную на работу с детьми с нарушением речи; вторая - ориентирует на формирование у будущих логопедов готовности к работе в развивающе-коррекиионном режиме (мотивации, потребности, способности, решимости к саморазвитию, рефлексии, эмпатии, творческой активности) с использованием инновационных форм, активнblх методов и информационно-коммуникачионных технологий; третья - направлена на развитие профессиональных умений и навыков, в частности через коррекционно-логопедической работь средствами моделирования артикуляиии звуков.

Ключевые слова: комплекс, педагогические условия, профессиональная подготовка, будушие логопеды, информационно-образовательная среда.

The article deals with the complex of pedagogical conditions of a professional training of intending speech therapists in an informational and educational environment of higher educational establishments. The interpretation of a complex of pedagogical conditions is presented, under which we understand a set of interrelated factors and measures of an educational process, the following of which ensures that students achieve a higher level of readiness for professional activity. The following groups of conditions are identified: the first group reflects the process of a purposeful use of the potential of professional disciplines in a professional training of intending speech therapists through a theoretical training and practice, which is aimed at working with children with speech disorder; the second is oriented on the formation of future speech therapists' readiness to work in a developmental and corrective mode (motivation, needs, abilities, determination to self-development, reflection, empathy, creative activity) using innovative forms, active methods and information and communication technologies; the third group is aimed at professional skills development, in particular, through correction and speech therapy by means of modeling articulation of sounds.

It is proved that the first group of conditions includes: a theoretical training of intending speech therapists, which is aimed at working with children with speech disorder; some additions to the content of educational disciplines and implementation of the developed special seminars "An innovative activity of a speech therapist», "The formation of a professional competence of an intending speech therapist», "Working with children with speech development disorder», concerning the solution 
to this problem, are embodied in an integrated interdisciplinary program of training of working with children with speech disorder. A practical activity of intending speech therapists on working with children with speech disorder was carried out during students' practical training. The second group of conditions presupposes the use of innovative forms, active methods and educational technologies. For the implementation of the third group of conditions, sound articulation models are proposed, which are experimentally tested in a speech correction training of students creating great opportunities for the formation of correctional knowledge, skills and abilities than traditionally recommended methods.

Key words: complex, pedagogical conditions, professional training, intending speech therapists, informational and educational environment.

Процеси, що відбуваються в системі вищої педагогічної освіти, зумовлені чинниками (умовами), які визначають вектори подальшого іiі розвитку. Ці ж чинники детермінують побудову сучасної моделі професійної підготовки майбутніх логопедів у закладі вищої освіти. Проблема створення моделі й моделювання процесу підготовки фахівців до професійної діяльності, розробка умов апробації моделі широко представлена в роботах В. Акименко, В. Антипова, С. Атанасяна, В. Введенського, О. Дружиловської, Е. Жукатинської, А. Прохорова, І. Сунагатулліної, В. Штоффа, Л. Ястребової та ін. Детальний аналіз основних визначень дає змогу стверджувати, що моделювання має об'єднувати різні процеси: проєктування моделі шляхом відбору інформації з відповідної проблеми; використання необхідних елементів, частин для проведення різних субмодельних структур; формування висновків про досліджуваний об'єкт і предмет дослідження з метою отримання нового знання, досвіду. Під моделлю розумітимемо реалізацію спроєктованого педагогічного процесу в усіх складових компонентах - змісту, форм, методів, технологій навчання таким чином, щоб гарантовано отримати необхідний результат - досягнення спроєктованої освітньої мети, що можливе завдяки дотриманню певних вимог, умов чи чинників.

Під комплексом педагогічних умов підготовки майбутніх логопедів в інформаційно-освітньому середовищі закладів вищої освіти розуміємо сукупність взаємопов'язаних чинників та заходів освітнього процесу, дотримання яких забезпечує досягнення студентами більш високого рівня готовності до професійної діяльності.

Науковці вважають, що в закладі вищої освіти необхідно створити такі умови, які сприятимуть переходу на більш високі рівні готовності до професійної діяльності, зокрема у процесі формування професійної компетентності майбутніх фахівців (С. Мякішев [8]), спеціальної підготовки студентів (О. Дружилівська [4]), професійно-педагогічної компетентності майбутніх учителів-логопедів (С. Маринич [6]), соціально-педагогічної компетентності майбутніх учителів-логопедів (Р. Аслаєва [1], Т. Бойко [2]), професійної підготовки майбутніх логопедів до комплексного супроводу дітей 3 тяжкою мовленнєвою патологією (О. Васильєва [3]), професійної компетентності вчителя-логопеда (Л. Стахова [10]), підготовки майбутніх учителів до розвитку мовленнєвої діяльності молодших школярів (I. Сунагатуліна [11]), підготовки логопеда до роботи з дітьми раннього віку (Л. Федорович [12]), професійно значимих якостей майбутніх педагогів-дефектологів (Л. Ястребова [13]).
Мета статті - обгрунтувати комплекс педагогічних умов професійної підготовки майбутніх логопедів в інформаційно-освітньому середовищі закладів вищої освіти та розкрити їх специфіку.

Під час характеристики педагогічних умов, що забезпечують ефективність у підготовці майбутніх логопедів до роботи з дітьми $з$ мовленнєвими порушеннями, ми зважали на аналіз особливостей освітнього процесу в інформаційно-освітньому середовищі закладів вищої освіти, оскільки комплекс умов буде реалізовуватися саме через це середовище. Крім того, враховувалися своєрідність діяльності логопеда 3 такою категорією дітей, для яких характерне порушення мовлення, а також специфічність перебігу психічних процесів.

В основу реалізації педагогічних умов професійної підготовки майбутніх логопедів в інформаційно-освітньому середовищі закладів вищої освіти покладено матричний підхід, що дає змогу цілісно побачити експериментальну діяльність, спрямовану на реалізацію комплексу педагогічних умов, а також наочно показати способи реалізації цих умов, тобто готовність до роботи в розвивально-корекційному режимі, і формування необхідних якостей майбутнього логопеда для роботи з дітьми з порушенням мовлення через теоретичну та практичну підготовку їх до цієї діяльності. Розроблена матриця сприяла вирішенню проблеми теоретичної і практичної підготовки студентів до роботи 3 дітьми 3 порушенням мовлення, а також формуванню особистісних якостей майбутніх логопедів, необхідних для здійснення цієї діяльності.

Ураховуючи вищеозначене, нами виділено три групи умов: перша група відображає процес цілеспрямованого використання теоретичного потенціалу фахових дисциплін у професійній підготовці майбутніх логопедів та практичну діяльність, спрямовану на роботу з дітьми з порушенням мовлення; друга - орієнтує на формування в майбутніх логопедів готовності до роботи в розвивально-корекційному режимі (мотивації, потреби, здатності, рішучості до саморозвитку, рефлексії, емпатії, творчої активності) з використанням інноваційних форм, активних методів та інформаційно-комунікаційних технологій; третя група спрямована на розвиток професійних умінь $\mathrm{i}$ навичок, зокрема через корекційно-логопедичну роботу засобами моделювання артикуляції звуків.

У межах першої педагогічної умови, здійснюючи теоретичну підготовку майбутніх логопедів, спрямовану на роботу з дітьми з порушенням мовлення, зокрема в сучасному закладі дошкільної освіти, внесено деякі доповнення у зміст навчальних дисциплін, що стосуються вирішення цієї проблеми. Останнє знайшло своє відображення у змісті інтегрованої міждисциплінарної програми підготовки майбутніх логопедів до роботи з дітьми означеної категорії. Теоретична підготовка здійснюється і в процесі впровадження розроблених спецсемінарів («Інноваційна діяльність логопеда», «Формування професійної компетентності майбутнього логопеда», «Робота $з$ дітьми 3 порушенням мовленнєвого розвитку»). Водночас практична діяльність майбутніх логопедів щодо роботи з такими дітьми реалізувалася під час проходження студентами всіх видів практик.

Друга педагогічна умова передбачає формування в майбутніх логопедів готовності до роботи в розвивально-корекційному режимі (мотивації, потреби, здатності, рішучості до саморозвитку, рефлексії, емпатії, творчої активності) з використанням інноваційних форм, 
активних методів та інформаційно-комунікаційних технологій. У такому контексті мотивація - це вся сукупність стійких мотивів, спонукань, що визначають зміст, спрямованість і характер діяльності особистості, iї поведінки, а потреба - це потреба в чому-небудь об'єктивно необхідному для підтримки життєдіяльності й розвитку особистості, суспільства загалом. Задоволення потреб відбувається в результаті цілеспрямованої діяльності, тоді виховання потреб є одним із центральних завдань формування особистості [5, с. 113, 144].

У центрі педагогічної рефлексії знаходиться усвідомлення того, яким чином дитина сприймає і розуміє вихователя, ставлення до нього, а також як вона може налаштуватися на його дії [7, с. 24].

Під педагогічною рефлексією розуміємо здатність логопеда дати собі та своїм учинкам об'єктивну оцінку, зрозуміти, як його сприймають діти, інші люди, насамперед ті, із ким логопед взаємодіє у процесі педагогічного спілкування. При цьому емпатія у словнику-довіднику практичного психолога розглядається як якість особистості, іiі здатність проникати за допомогою почуттів у душевні переживання інших людей, співчувати їм, співпереживати. Емпатію важко виховати, але важко й зруйнувати. Вона зближує людей у спілкуванні, доводячи його до рівня довірчого, інтимного [5, с. 220].

Емпатія $€$ неодмінною професійно значущою особистісною якістю майбутнього логопеда.

Ще однією складовою готовності логопеда до роботи 3 дітьми 3 порушенням мовлення $є$ здібності. У психологічному словнику під здібностями розуміють індивідуально-психологічні особливості особистості, що $є$ умовою успішного виконання тієі чи іншої продуктивної діяльності. Вони тісно пов'язані із загальною спрямованістю особистості, з тим, наскільки стійкі схильності людини до тієї чи іншої діяльності. Способи проявляються в уміннях, навичках, способах діяльності, що використовуються людиною, зокрема у професійній праці. Ключовим словом, що відображає сутність здібностей, є слово «можу». Здібності - це те, що напрацьовується людиною в процесі всієї ії життєдіяльності [9, с. 269].

Воля і рішучість - ці два поняття тісно пов'язані між собою, але не замінюють один одного. Якщо воля це здатність людини діяти в напрямі свідомо поставленої мети, долаючи зовнішні і внутрішні перешкоди, то рішучість - це внутрішній стимул до дії, непов'язаний i3 проявом насильства людини над собою, це енергія природної дієвості людини. Людина це робить, оскільки це іiі сутність, тому суть цього поняття відображає дієслово «роблю». У педагогічному процесі формування волі вихованців займає почесне місце, оскільки без сформованості вольових якостей (цілеспрямованості, дисципліни, організованості, наполегливості, витримки, самовладання, рішучості) вихованцю важко реалізувати свої потенційні можливості в повному обсязі.

Для формування креативності як особистісної, а не тільки поведінкової властивості потрібно спеціальним чином організоване середовище. «Локальні» методики розвитку креативності (наприклад, вирішення нестандартних завдань), безумовно, корисні. Проте в результаті їхнього застосування студенти засвоюють деякі нові способи вирішення і згодом відтворюють засвоєний спосіб дій. У таких випадках креативність проявляється у відповідь на зовнішні впливи, а не з особистих потреб суб'єкта. Саме тому для формування креативності як особистісної властивості потрібне спеціальне середовище, що забезпечує багатосторонній системний вплив на студента.

Водночас інформаційно-комунікаційні технології допомагають забезпечити тісний контакт між викладачем і студентами навіть в умовах дистанційної освіти. Така взаємодія обумовлює розвиток творчих здібностей. Щодо соціального підкріплення проявів креативності, то тут інформаційно-освітнє середовище надає найширші можливості. Опис творчого процесу, його результати можуть бути представлені та обговорені на інтернет-конференції, опубліковані в електронному науковому виданні, розміщені на вебсайті навчального закладу як органічний компонент інформаційно-освітнього середовища.

Інформаційно-комунікаційні технології розширюють можливості освітнього середовища як різноманітними програмними засобами, так і методами розвитку креативності студентів. До числа таких програмних засобів необхідно віднести моделювальні програми, пошукові системи, інтелектуальні навчальні системи, експертні системи, програми для проведення ділових ігор. Фактично в усіх сучасних електронних підручниках робиться акцент на розвитку творчого мислення. 3 цією метою в них пропонуються завдання евристичного, творчого характеру, ставляться питання, на які неможливо дати однозначну відповідь тощо. Комунікаційні технології дозволяють по-новому реалізовувати методи, що активізують творчу активність. Дискусії, «мозкові штурми» можуть проводитися не тільки в аудиторії, а й віртуально, що дозволяє брати участь у них усім студентам, незалежно від форми навчання. При цьому до виконання спільних творчих проєктів можуть залучатися студенти, які навчаються в різних закладах.

Новий зміст інформаційно-освітнього середовища створює і додаткові можливості для стимулювання допитливості студента. Одним із таких стимулів є задоволення своєї цікавості завдяки широким можливостям глобальної мережі Інтернет. Студентам надається доступ до електронних бібліотек (науково-технічних, науково-методичних, довідкових тощо), інтерактивних баз даних культурних, наукових та інформаційних центрів, енциклопедій, словників. Крім того, існують «списки розсилки», що дають змогу отримувати електронною поштою добірки матеріалів із «вузьких» тем. Через Iнтернет студенти можуть звернутися із проблемою не тільки до свого безпосереднього наставника, але й до провідних вітчизняних та зарубіжних фахівців, винести iii на обговорення в електронній конференції або чаті. Саме різноманітність інформації, що пропонується в освітньому середовищі, інтегрованої у світовий інформаційний простір, допомагає педагогу підвести студентів до пошуку власного погляду на суть досліджуваної проблеми. Розвитку допитливості студентів, прищеплення інтересу до пошуково-дослідницької діяльності допомагає також можливість роботи в віртуальних наукових лабораторіях, проведення комп'ютерних експериментів за допомогою моделювальних програм.

Створювані на сайтах навчальних закладів персональні вебсторінки педагогів (другий рівень інформаційно-освітнього середовища) відкривають додаткові можливості студентам для творчості. На таких сторінках можна виставити не тільки навчальні матеріали, а й свої наукові публікації, проспекти проведених досліджень, найкращі роботи студентів. Опублікувавши нестандартне або навіть провокаційне бачення тієї чи іншої проблеми, можна організувати дискусію, спонукаючи таким чином студентів до висловлення власної думки. 
Вихід у світовий інформаційний простір дозволяє студентам побачити безліч зразків креативності: на сайтах, що розповідають про діяльність науково-дослідних центрів та окремих науково-дослідних інститутів; у матеріалах електронних наукових журналів і конференцій, результатах конкурсів творчих проєктів і дистанційних олімпіад; на персональних вебсторінках студентів, викладачів, науковців усього світу.

Третя педагогічна умова - розвиток професійних умінь, навичок, компетентностей, зокрема через корекційно-логопедичну роботу засобами моделювання артикуляції звуків. Упродовж останнього десятиліття в системі вищої освіти відбулися зміни в напрямі створення нових закладів вищої освіти та технологій навчання. Усе це в комплексі сприяє тій ревізії, якій багато викладачів піддають раніше використовувані методи й технології навчання, підходи до оцінки якості знань студентів. Одним із основних факторів, що визначають необхідність таких змін, є нагальна вимога сьогоднішнього дня до знань і навичок дипломованого фахівця це і мобільність в отриманні все нових і нових знань, високі комунікативні якості та вміння працювати в команді, що поєднується з ініціативністю і самостійністю.

Як наслідок, заклади вищої освіти намагаються запропонувати різноманітні форми навчання - денну, дистанційну, заочну, скорочену тощо. Водночас слід очікувати, що в майбутньому студенти будуть віддавати перевагу найбільш вільним формам, що дають змогу отримувати необхідні їм знання найбільш зручним для них способом.

Висновки. Отже, у процесі дослідження нами визначено такі групи педагогічних умов професійної підготовки майбутніх логопедів в інформаційно-освітньому середовищі закладів вищої освіти: перша група відображає процес цілеспрямованого використання потенціалу фахових дисциплін у професійній підготовці майбутніх логопедів через теоретичну підготовку та практичну діяльність, спрямовану на роботу з дітьми 3 порушенням мовлення; друга - орієнтує на формування у майбутніх логопедів готовності до роботи в розвивально-корекційному режимі (мотивації, потреби, здатності, рішучості до саморозвитку, рефлексії, емпатії, творчої активності) з використанням інноваційних форм, активних методів та інформаційно-комунікаційних технологій; третя група спрямована на розвиток професійних умінь і навичок, зокрема через корекційно-логопедичну роботу засобами моделювання артикуляції звуків. Перша група педагогічних умов включала: теоретичну підготовку майбутніх логопедів, спрямовану на роботу 3 дітьми 3 означеними проблемами; деякі доповнення у змісті навчальних дисциплін та впровадження розроблених спецсемінарів «Інноваційна діяльність логопеда», «Формування професійної компетентності майбутнього логопеда», «Робота 3 дітьми 3 порушенням мовленнєвого розвитку», що втілилося в інтегровану міждисциплінарну програму підготовки майбутніх логопедів до роботи 3 дітьми 3 порушенням мовлення. Практична діяльність майбутніх логопедів здійснювалася під час проходження студентами всіх видів практик. Друга група умов передбачала використання інноваційних форм, активних методів та освітніх технологій. Для реалізації третьої групи умов запропоновано моделі артикуляції звуків, які експериментально перевірені в навчанні студентів-логопедів корекції звуковимови в дітей, що створюють значно ширші можливості для формування знань, умінь і навичок корекційної роботи, ніж традиційно рекомендовані способи.
Перспективу подалыших досліджень вбачаємо в реалізації та експериментальній перевірці запропонованого комплексу педагогічних умов професійної підготовки майбутніх логопедів в інформаційно-освітньому середовищі закладів вищої освіти.

\section{СПИСОК ВИКОРИСТАНОЇ ЛІТЕРАТУРИ}

1. Аслаева Р. Г. Стратегия социально-профессиональной подготовки дефектологов в педагогическом вузе : дис. ... д-ра пед. наук / Р. Г. Аслаева. - Уфа, 2011. - 497 c.

2. Бойко Т. Н. Формирование социально-педагогической компетентности будущих учителей-логопедов в процессе педагогической практики : дис. ... канд. пед. наук / Т. Н. Бойко. - Брянск, 2016. - 211 с.

3. Васильева Е. Е. Профессиональная подготовка будущих логопедов к комплексному сопровождению детей с тяжелой речевой патологией / Е. Е. Васильева // Ярославский педагогический вестник. - 2017. № 2. - С. 152-159.

4. Дружиловская О. В. Современный подход к преподаванию дисциплин медико-биологического цикла на дефектологических факультетах педагогических вузов : дис. ... канд. пед. наук / О. В. Дружиловская. - Москва, 2003. - 210 с.

5. Конюхов Н. И. Словарь-справочник практического психолога / Н. И. Конюхов. - Воронеж : НП «МОДЭК», 1996. - 224 c.

6. Маринич Е. Е. Формирование профессионально-педагогической компетентности будущего учителя-логопеда в вузе : автореф. дис. на соискание ученой степени канд. пед. наук / Е. Е. Маринич. - Шуя, 2012. - 24 c.

7. Мудрик А. В. Учитель: мастерство и вдохновение / А. В. Мудрик. -Москва : Просвещение, 1986. $160 \mathrm{c}$.

8. Мякишев С. Л. Информационно-образовательная среда вуза как фактор формирования профессиональной компетентности будущих педагогов : дис. ... канд. пед. наук / С. Л. Мякишев. - Киров, 2007. $167 \mathrm{c}$.

9. Психологический словарь / под ред. М. И. Дьяченко, Л. А. Кандыбовича. - Минск : Хэлтон, 1998. 399 c.

10. Стахова Л. Л. Проектирование методической системы развития профессиональной компетентности учителя-логопеда дошкольного образовательного учреждения в условиях профессиональной среды : дис. ... канд. пед. наук / Л. Л. Стахова. - Тамбов, 2010. - 195 с.

11. Сунагатуллина И. И. Подготовка будущих учителей к развитию речевой деятельности младших школьников в современной общеобразовательной школе : дис. ... канд. пед. наук / И. И. Сунагатуллина. Магнитогорск, 2006. - 197 с.

12. Федорович Л. О. Концептуальні засади підготовки логопеда до роботи 3 дітьми раннього віку у вищих навчальних закладах в умовах інтеграції в європейський освітній простір / Л. О. Федорович // Науковий часопис. Корекційна педагогіка. - 2012. № 12 . - С. 286-290.

13. Ястребова Л. А. Формирование профессионально значимых качеств будущих педагогов-дефектологов : дис. ... канд. пед. наук / Л. А. Ястребова. Армавир, 2008. - 167 с.

Дата надходження до редакиії: 02.09.2019 p. 